\title{
Control weld geometric parameters when wet underwater welding*
}

\author{
${ }^{1}$ Han Yanfei, ${ }^{2}$ Guo Ning, ${ }^{3}$ Feng Jicai \\ ( 1 韩炎飞, 2 郭 宁, 3 冯吉才) \\ ${ }^{1}$ Institute of Materials Joining, Shandong University, Jinan 250061, China \\ hanyanfei106@163.com, ORCID 0000-0001-8598-4413 \\ 2Shandong Provincial Key Laboratory of Special Welding Technology, \\ Harbin Institute of Technology at Weihai, China, gn21c@126.com \\ ${ }^{3}$ State Key Laboratory of Advanced Welding and Joining, Harbin \\ Institute of Technology, Harbin 150001, China, fengjc@hit.edu.cn
}

Received 11.04.2020, accepted after revision 25.05.2020

https://doi.org/10.32347/uwt2020.10.1401

\begin{abstract}
The aquatic environment has a significant impact on the efficiency of heat input to the base metal, significantly reducing the efficiency of the arc. As a result, in wet underwater welding, the penetration of the base metal is reduced compared to welding in the air with the same mode parameters. The purpose of the research was to determine the effectiveness of the influence of the parameters of the process of underwater wet welding with rutile-type flux-cored wire on the geometric parameters of the weld metal - its width and penetration depth of the base metal. In this case, the shape coefficient of the weld was determined - the ratio of width to penetration depth (W/P). It was found that the welding speed, wire feed speed and the amplitude of the welding torch oscillations have a significant impact on the ratio of the width to the penetration depth of the welds. The W/P ratio of welds decreases significantly with increasing welding speed without oscillation of the welding torch. So, when welding with transverse oscillations of the welding torch with an increase in the wire feed speed, it decreased from 7.14 to 3.85. And it linearly increased with increasing amplitude
\end{abstract}

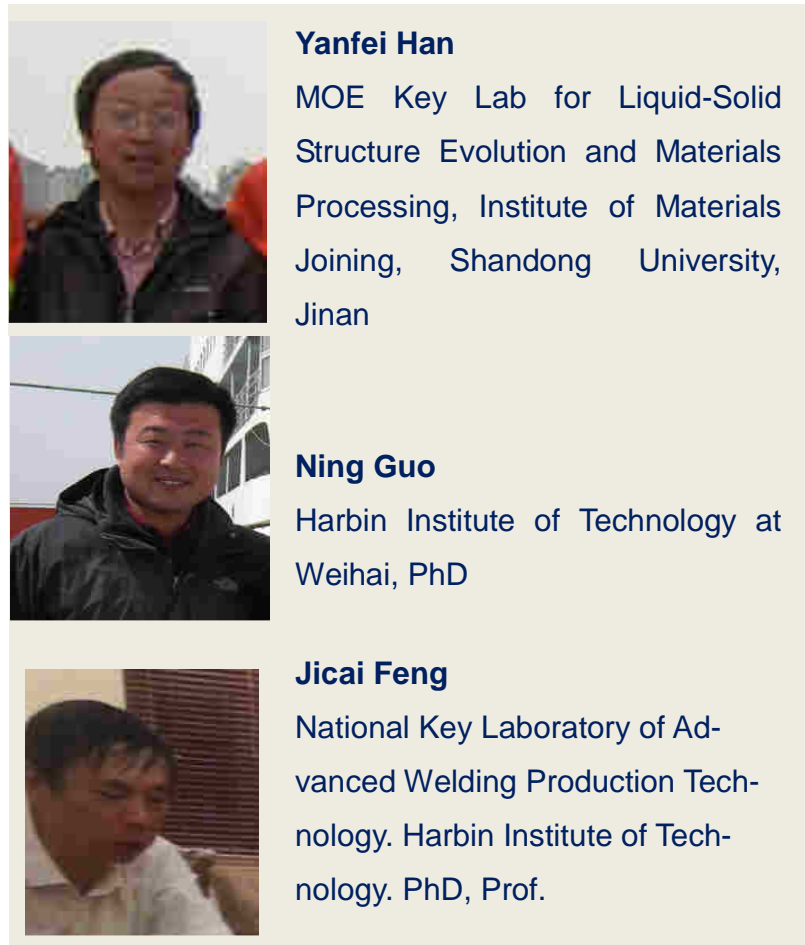

of the torch oscillations. It was found that the oscillation velocity, elongation of the flux-cored wire, and arc voltage have an insignificant effect on the W/P ratio.

Keywords: flux-cored wire, underwater wet welding, width-to - penetration depth ratio.

\footnotetext{
* Supported by State Key Laboratory of Advanced Welding and Joining, Harbin Institute of Technology, supported by a grant from the National High Technology Research and Development Program of China (No. 2008AA092901) and a grant from International Science and Technology Cooperation Program of China (No. 2011DFR50020).
} 


\section{INTRODUCTION}

Underwater welding can be divided into three categories according to the operating environment, namely, wet, dry, and local dry welding $[1,2]$. Wet welding is the simplest one in the three methods and has the most widely engineering adaptability [3]. It can work directly in the water without any special drainage facilities. The advantages of wet welding are simple equipment, low cost, flexible operation, and strong adaptability and so on [4, 5]. At present the most commonly used method is underwater shielded metal arc welding (SMAW) [6]. However, it needs divers to dive for welding. The time of each dive welder working in the water is very limited and it decreases with the increase of water depth. In addition, restricted by the length of the electrode, it needs to replace electrode frequently in the welding process, which extends the underwater construction time and leads to low production efficiency. And the quality is also difficult to guarantee [7]. The arc will be unstable when working in the water more than $80 \mathrm{~m}$ with solid wire gas shielded welding such as GMAW [8]. The main problems of this method are arc breaking and metal particles splashing [9]. Compared with solid wire, the metal and powder in flux-cored wire can interact more effectively in the heat distribution. And it can improve the arc ionization conditions efficiently and promote the stability of the transition metal thanks to the addition of the solder flux [10]. So the advantages of flux-cored wire are more prominent when used for welding in the deep water $[11,12]$. Of course, the weld- ing efficiency of flux-cored wire is significantly improved compared with SMAW. The emergence of flux-cored wire will promote the underwater welding production to the development of high-efficiency, low-cost, high-quality, automation, and intelligence [13].

The basic research of flux-cored wire underwater wet welding involves a large number of objects. There is no special flux-cored wire for underwater wet welding in China. So this paper mainly studied the effects of process parameters on the W/P ratio of rutile type flux-cored wire underwater wet welding with a flux-cored wire manufactured in the Institute of Oceanographic Instrumentation, Shandong Academy of Sciences, Qingdao. Due to the penetration and melting width are important parameters for weld formation, the W/P ratio of welds can reflect to some extent the characteristics of the method and the qualified degree of weld size.

\section{EXPERIMENTAL METHODS AND MATERIALS}

The base metal used in this paper is shipbuilding steel plate CCSE40 ( $\sigma \mathrm{T}=390 \mathrm{M \Pi а})$ and the size of specimen is $200 \times 100 \times 14 \mathrm{~mm}$. Its chemical composition is given in Table 1.

The diameter of flux-cored wire is $1.6 \mathrm{~mm}$. The wire is made with low carbon steel strip of which the size is $8 \times 0.3 \mathrm{~mm}$. The welding type used in this paper is D.C. plate welding. The torch is designed for reciprocating oscillating in the perpendicular direction of the forward

Table 1. Chemical composition of CCSE40 steel plate (wt. \%)

\begin{tabular}{|c|c|c|c|c|c|c|c|c|}
\hline $\mathrm{C}$ & $\mathrm{Mn}$ & $\mathrm{Si}$ & $\mathrm{S}$ & $\mathrm{P}$ & $\mathrm{Mo}$ & $\mathrm{Ni}$ & $\mathrm{Cr}$ & $\mathrm{V}$ \\
\hline$\leq 0.18$ & 1.2 & $\leq 0.5$ & $\leq 0.035$ & $\leq 0.035$ & $\leq 0.08$ & $\leq 0.4$ & $\leq 0.20$ & 0.06 \\
\hline
\end{tabular}


direction. There is no dwell time on both sides of the torch oscillating. The amplitude and speed of oscillating can be changed individually. The test is carried out in a glass tank, of which the size is $900 \times 450 \times 400 \mathrm{~mm}$. And the tank is filled with fresh water, the depth of which is $0.3 \mathrm{~m}$. The temperature of water used in this paper is $20 \square$ and the main

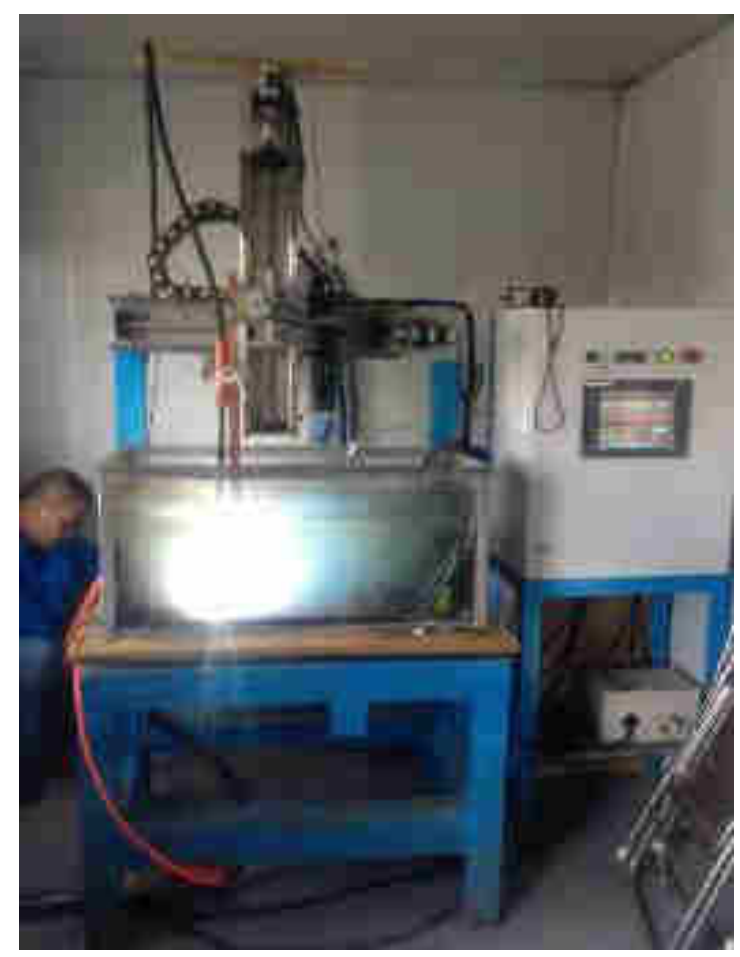

$a$ equipment's are showed in Fig.1. It needs to remove the rust on the specimen with the method of mechanical grinding before welding. Vernier caliper is used to measure the penetration and width of welds to research the effect of different parameters on the W/P ratio after cutting the specimens transversely.

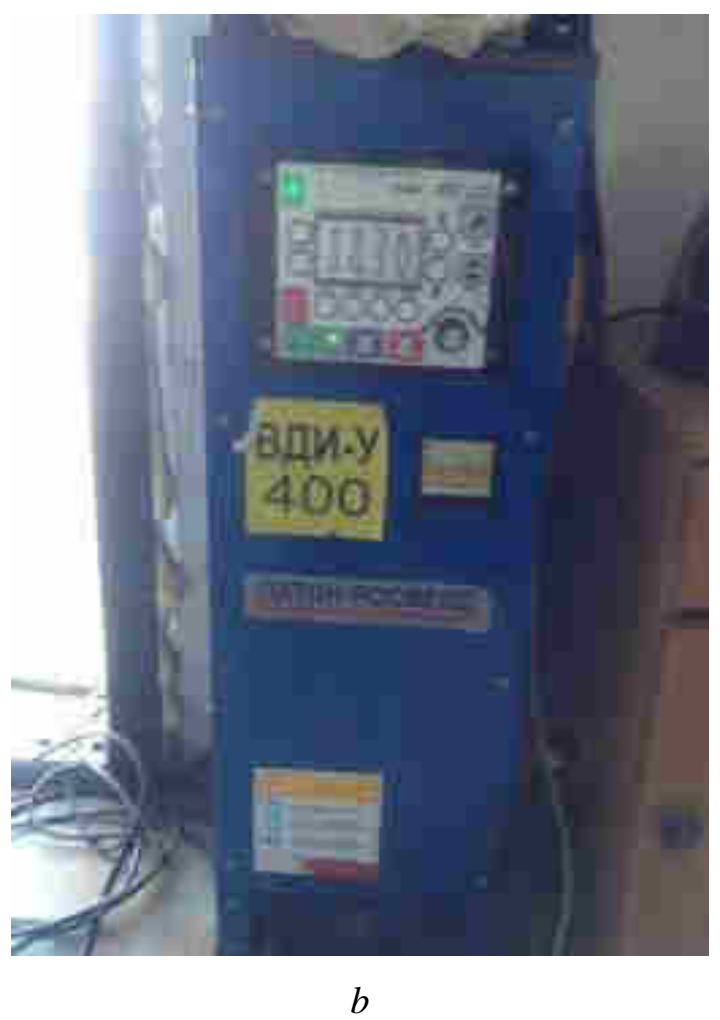

Fig.1. Welding equipment: $a$-welding tank and control system, $b$ - power source

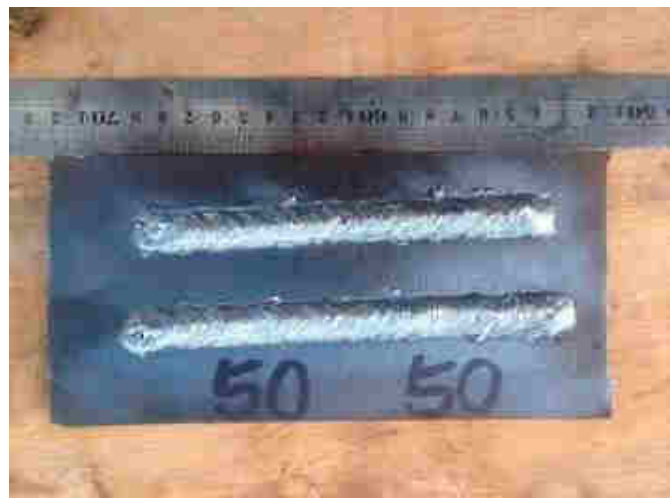

$a$

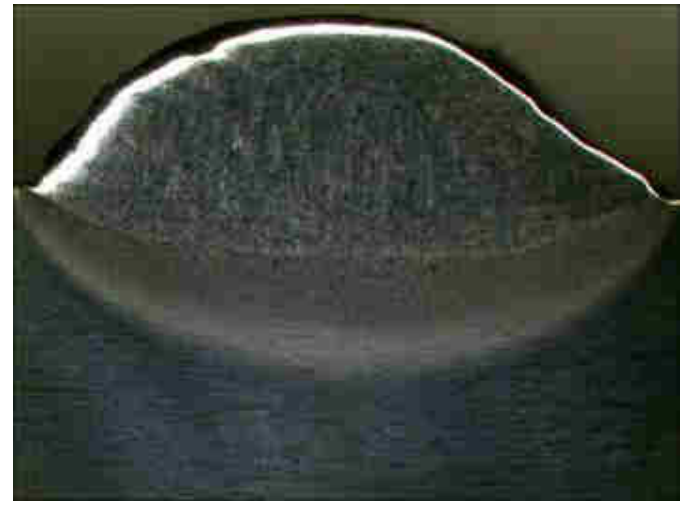

$b$

Fig.2. Formation and macro morphology of welds appear quite visible: 


\section{RESULT AND DISCUSSION}

\section{Formation and macro morphology of welds}

Fig. $2 a$ shows the formation of weld that welded with the homemade flux-cored wire. As seen in the figure, it exhibits an excellent appearance on the specimen. There are no obvious defects on the surface of welds, except a little spatter. Fig. $2 b$ shows the macro morphology of cross section surface on the weld. As shown in the figure, there is no slag or crack in the weld. The welding material combines closely with the base metal and the boundaries of each area.

\section{The effect of welding speed on the W/P ratio of welds}

In this paper, W1 and P1 stands for the width and penetration depth of welds that welded without torch oscillating, meanwhile, W2 and P2 stands for the width and penetration depth of welds that welded with torch oscillating.

The effect of welding speed on the W/P ratio of welds is showed in Fig.3a. And the experimental result is obtained with welding

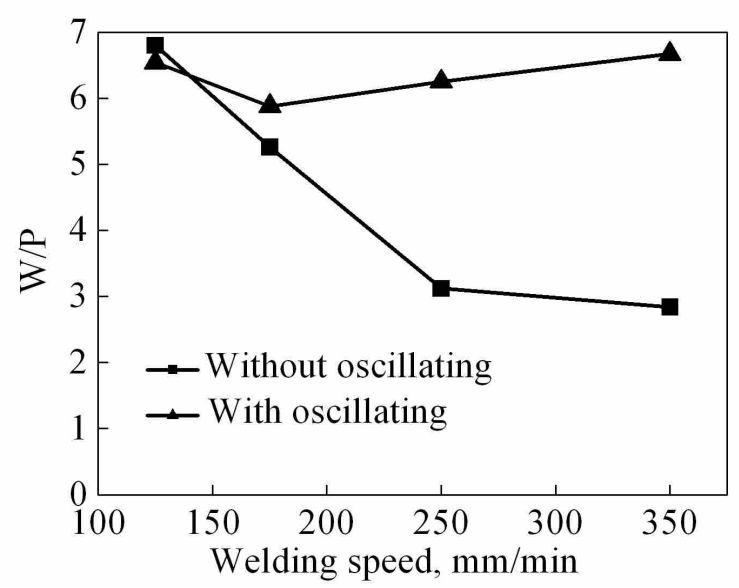

$a$ voltage of $31 \mathrm{~V}$, wire feeding speed of 3.3 $\mathrm{m} / \mathrm{min}$, wire extension of $20 \mathrm{~mm}$ and without torch oscillating. As showed in Fig. $3 a$, the $\mathrm{W} / \mathrm{P}$ ratio of welds decreases with the increasing of welding speed. The W/P ratio of weld increases significantly with the increasing of welding speed when the welding speed increases from $125 \mathrm{~mm} / \mathrm{min}$ to $250 \mathrm{~mm} / \mathrm{min}$. It also decreases with the increase of the welding speed when the welding speed increases from $250 \mathrm{~mm} / \mathrm{min}$ to $350 \mathrm{~mm} / \mathrm{min}$, but the trend of decreasing slows down apparently. This is because the width of welds decreases rapidly with the increase of welding speed, while the penetration depth of welds maintains within a small range of fluctuation. This trend is showed clearly in Fig. $3 b$.

Another line in Fig. $3 a$ shows the effect of welding speed on the W/P ratio of welds when the oscillating amplitude is $5 \mathrm{~mm}$ and the oscillating speed is $1000 \mathrm{~mm} / \mathrm{min}$. It changes within a small range when the welding speed increases from $125 \mathrm{~mm} / \mathrm{min}$ to 350 $\mathrm{mm} / \mathrm{min}$. The trend is not as obvious as that without the torch oscillating. It can accelerate the heat dissipating to the water when the torch oscillates actively, resulting in reducing the heat input to the base material. So the

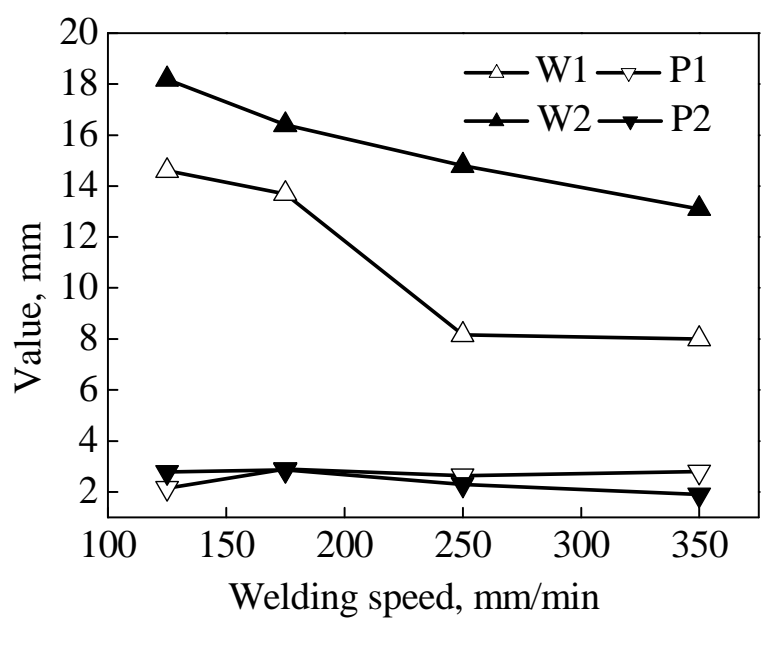

$b$

Fig.3. Effect of welding speed on W/P ratio: $a-\mathrm{D} / \mathrm{W}$ ratio of welds, $b$ - penetration depth and width of welds 


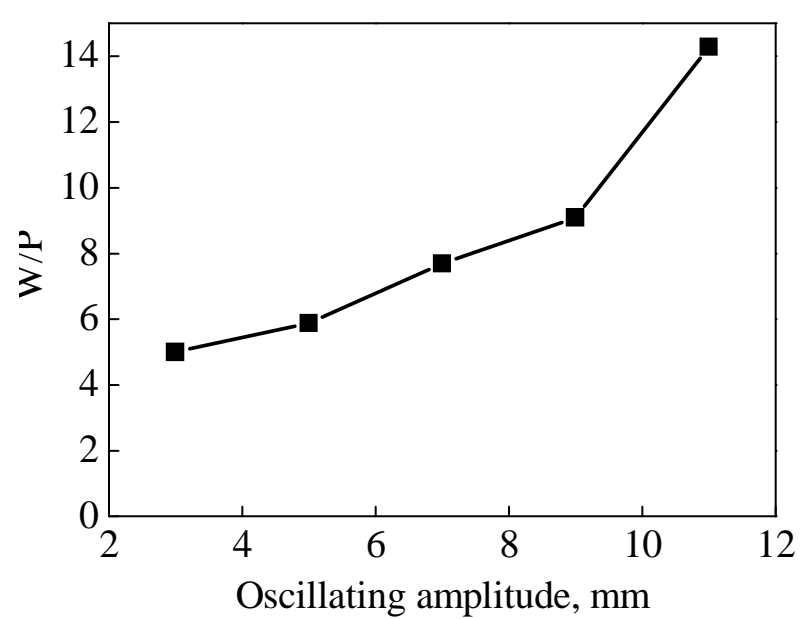

$a$

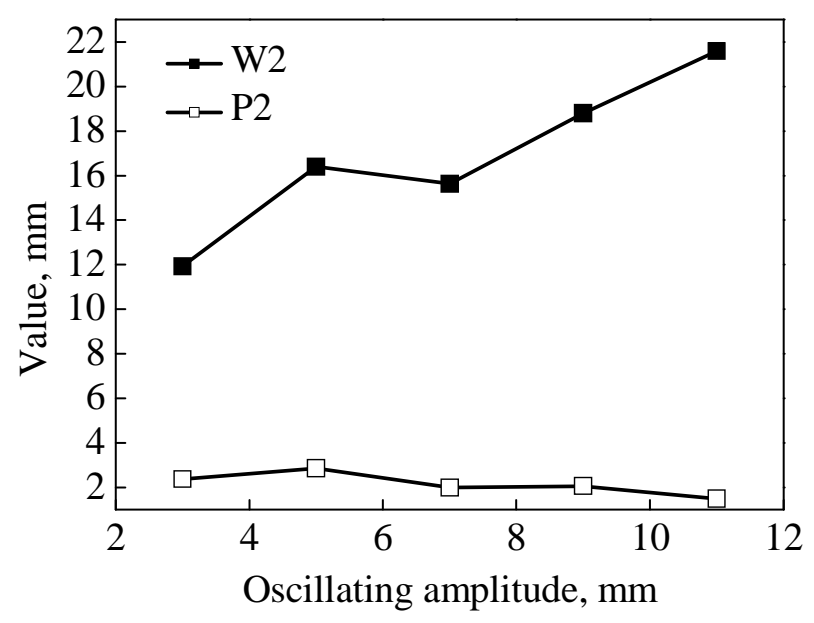

$b$

Fig.4. Effect of torch oscillating amplitude on W/P ratio: $a-$ W/P ratio of welds; $b$ - Penetration depth and width of welds

$\mathrm{W} / \mathrm{P}$ ratio of welds is larger than that when the torch does not oscillate.

\section{The effect of torch oscillating amplitude on the $W / P$ ratio of welds}

The effect of torch oscillating amplitude on the penetration depth-to-width ratio of welds is showed in Fig.4a. The experimental conditions of this part are as follows. The welding voltage is $31 \mathrm{~V}$, the wire feeding speed is $3.3 \mathrm{~m} / \mathrm{min}$, the wire extension is $20 \mathrm{~mm}$, the welding speed is $175 \mathrm{~mm} / \mathrm{min}$ and the torch oscillating speed is $1000 \mathrm{~mm} / \mathrm{min}$.

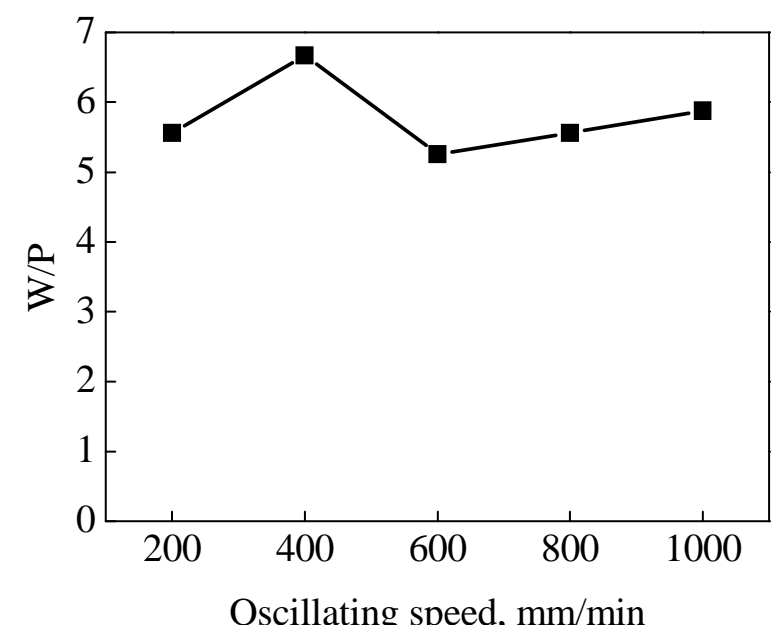

$a$
It can be seen from Fig. $4 a$ that the W/P ratio of welds increases linearly with the increase of torch oscillating amplitude. It is obvious that the width of welds would increase with the increase of torch oscillating amplitude, just as shown in Fig. $4 b$. In the case of other parameters remains unchanged and the heat input remains all the same, the depth of penetration would not change apparently, however, the width of welds would increase, which could cause the increase of W/P ratio of welds.

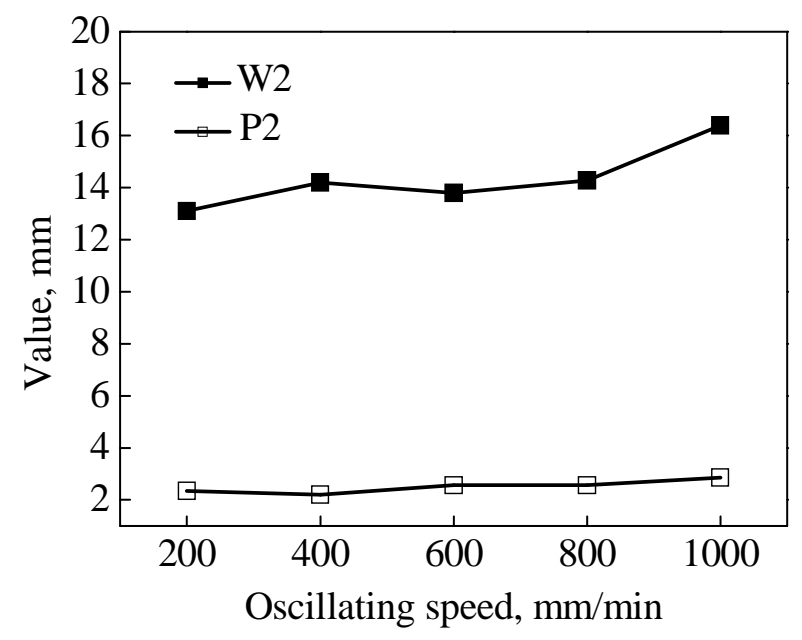

$b$

Fig.5. Effect of torch oscillating speed on W/P ratio: $a-\mathrm{W} / \mathrm{P}$ ratio of welds;

$b-$ penetration depth and width of welds 


\section{The effect of torch oscillating speed on the W/P ratio of welds}

The effect of torch oscillating speed on the W/P ratio of welds is showed in Fig.5a. The experimental conditions of this part are as follows. The welding voltage is $31 \mathrm{~V}$, the wire feeding speed is $3.3 \mathrm{~m} / \mathrm{min}$, the wire extension is $20 \mathrm{~mm}$, the welding speed is 175 $\mathrm{mm} / \mathrm{min}$ and the torch oscillating amplitude is $5 \mathrm{~mm}$. As can be seen from the figure, there is no clear trend for the W/P ratio in pace with the increase of the torch oscillating speed. The W/P ratio is maintained within a small range $(5.26-6.67)$ of fluctuation. In other words, the effect of the torch oscillating speed to W/P is not obvious and the changing of the torch oscillating speed could not cause bad weld formation. Fig. $5 b$ shows that the depth and width of welds also maintains within a small range.

\section{Effect of wire extension on the W/P ratio of welds}

The effect of wire extension on the W/P ratio of welds without torch oscillating is conditions of this part are as follows. The welding voltage is $31 \mathrm{~V}$, the wire feeding

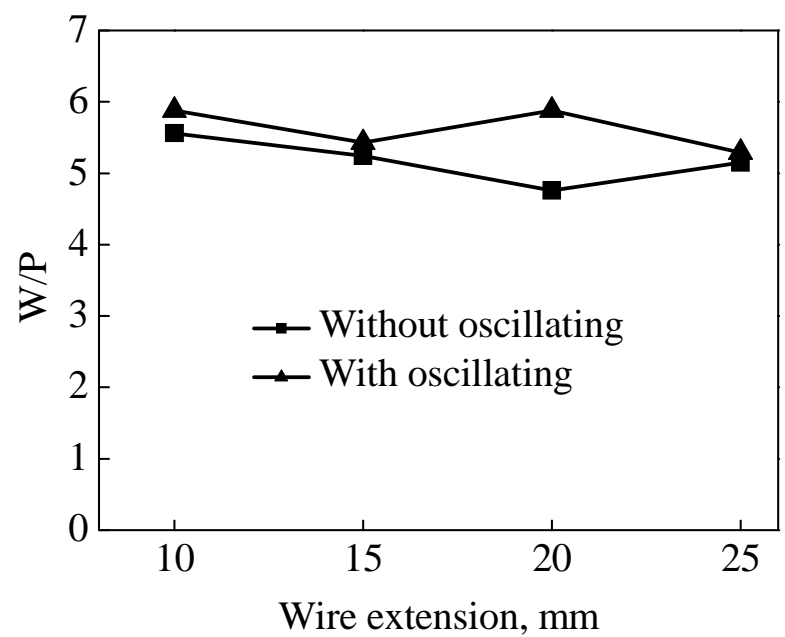

$a$ speed is $3.3 \mathrm{~m} / \mathrm{min}$ and the welding speed is $175 \mathrm{~mm} / \mathrm{min}$. As can be seen from the figure, the $\mathrm{W} / \mathrm{P}$ ratio first decreases with the increase of wire extension (from $10 \mathrm{~mm}$ to $20 \mathrm{~mm}$ ) and then increases showed in Fig.6 $a$. And the experimental with the increase of wire extension (from $20 \mathrm{~mm}$ to $25 \mathrm{~mm}$ ). But the variation range of the $\mathrm{W} / \mathrm{P}$ ratio is not great. Namely, the minimum value is 4,76 , and the maximum value is only 5,56 . The penetration depth and the width of welds change in a small range with the increase of wire extension, just as been showed in Fig. $6 b$.

The effect of wire extension on the W/P ratio of welds with torch oscillating is showed in Fig. $6 a$. All the other parameters of this part are the same as above except the followings. The torch oscillating amplitude is $5 \mathrm{~mm}$ and its oscillating speed is 1000 $\mathrm{mm} / \mathrm{min}$. As been showed in Fig. $6 a$, the W/P ratio of welds changes in a small range (from 5,26 to 5,88 ) with the increase of wire extension. Thus, regardless of whether the welding torch oscillates, the effect of wire extension on the penetration depth-to-width ratio of welds is not significant.

\section{Effect of welding voltage on the $W / P$ ratio of welds}

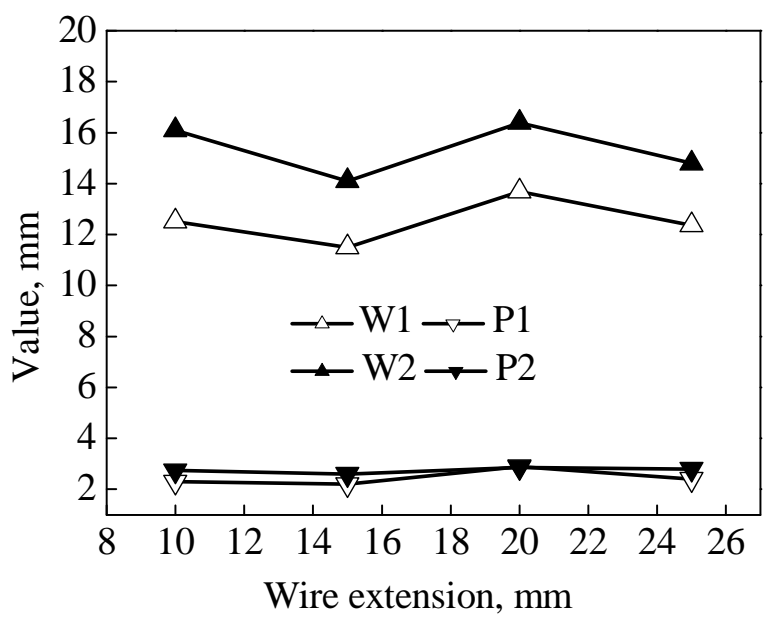

$b$

Fig.6. Effect of wire extension on W/P ratio: $a-\mathrm{W} / \mathrm{P}$ ratio of welds; $b-$ depth and width of welds 


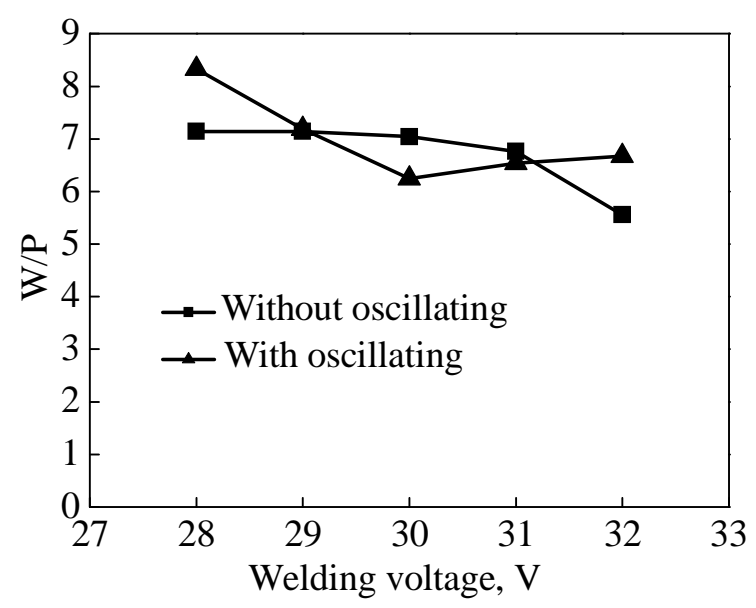

$a$

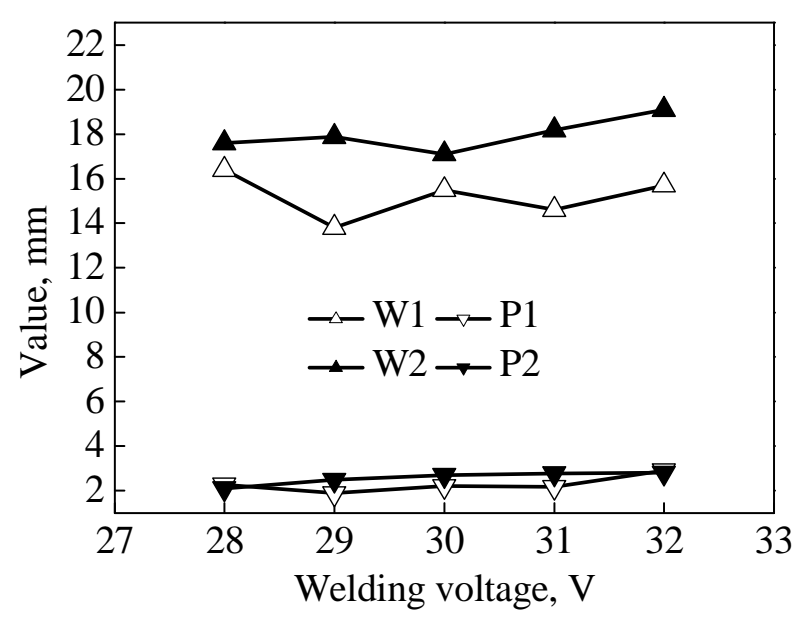

$b$

Fig.7. Effect of welding voltage on W/P ratio: $a-\mathrm{W} / \mathrm{P}$ ratio of welds; $b-$ Penetration depth and width of welds

The effect of welding voltage on the W/P ratio of welds without torch oscillating is showed in Fig.7a. The parameters of this part are as follows. The wire feeding speed is 3.3 $\mathrm{m} / \mathrm{min}$ and the welding speed is $175 \mathrm{~mm} / \mathrm{min}$. As can be seen from Fig.7a, the W/P ratio of welds decreases smoothly with the increase of welding voltage and its changing range is not large, only from 5,56 to 7,14 . This is because the penetration depth and width of welds changed smoothly with the increase of welding voltage, just as been showed in

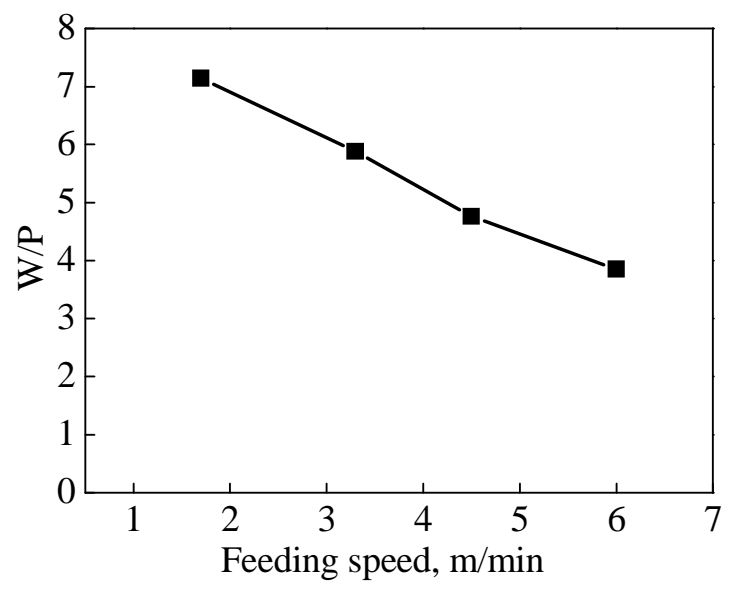

$a$
Fig.7b.

The effect of welding voltage on the W/P ratio of welds with torch oscillating is also showed in Fig.7a. All the other parameters of this part are the same as above except the followings. The torch oscillating amplitude is $5 \mathrm{~mm}$ and its oscillating speed is 1000 $\mathrm{mm} / \mathrm{min}$. It is showed in Fig.7 $a$ that the W/P ratio of

welds first decreases and then increases with the increase of welding voltage. However, the changing range of the W/P ratio of welds is not large. Namely, the minimum value is 6,25

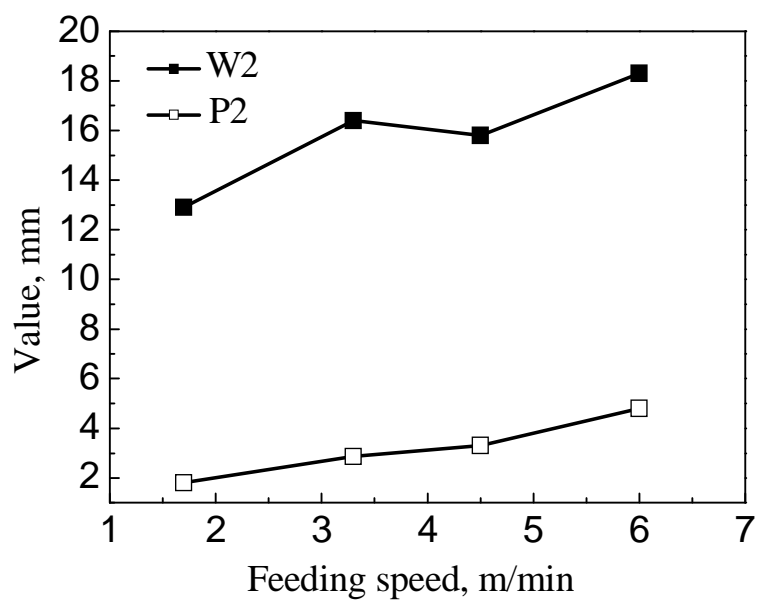

$b$

Fig.8. Effect of wire feeding speed on W/P ratio: $a-\mathrm{W} / \mathrm{P}$ ratio of welds;

$b-$ Penetration depth and width of welds 
and the maximum is just 8,33 . In a word, no matter whether the welding torch oscillate, the effect of welding voltage on the penetration depth-to-width ratio of welds is not great. The W/P ratio of welds is not sensitive to the change of welding voltage within the scope of this paper.

\section{The effect of wire feeding speed on the $W / P$ ratio of welds}

The effect of wire feeding speed on the W/P ratio of welds is showed in Fig.8 $a$. The parameters of this part are as follows. The welding voltage is $31 \mathrm{~V}$, the wire extension is $20 \mathrm{~mm}$, the welding speed is $175 \mathrm{~mm} / \mathrm{min}$, the torch oscillating amplitude is $5 \mathrm{~mm}$ and its oscillating speed is $1000 \mathrm{~mm} / \mathrm{min}$. As seen from Fig. $8 a$, the W/P ratio of welds decreases (from 3,85 to 7,14 ) with the increase of wire feeding speed.

The reasons for this phenomenon are as follows. In the flux-cored wire welding, increasing the wire feeding speed will cause increasing the welding current. In the case of other conditions remain unchanged, the increasing of welding current means that the increasing of heat input to the base metal, which will lead to the increasing of penetration depth and width of welds, Fig. $8 b$. Therefore, the W/P ratio of welds decreases with the increase of wire feeding speed. It is obviously showed in Fig.8a. But if increase the wire feeding speed continually, the welding process would not be stable and a bad formation of welds can be got. So the W/P ratio of welds is not showed in this paper when the wire feeding speed increased greater than $6 \mathrm{~m} / \mathrm{min}$.

\section{CONCLUSIONS}

1. Under the condition that without welding torch oscillating, the W/P ratio of welds increases significantly with the increase of welding speed. And it increases (from 3,85 to $7,14)$ with the increase of wire feeding speed.

2 . The W/P ratio of welds changes within a small range in pace with the increase of welding speed while the welding torch oscillating. It increases linearly with the increase of torch oscillating amplitude. But the effect of torch oscillating speed to the W/P ratio of welds is not obvious and the changing of the torch oscillating speed would not cause bad weld formation.

3. Regardless of whether the welding torch oscillating, the effect of wire extension on the $\mathrm{W} / \mathrm{P}$ ratio of welds is not significant. And the W/P ratio of welds is not sensitive to the changing of welding voltage within the scope of this paper.

\section{REFERENCES}

1. Michale A., 1998. Underwater wet welding became a viable option. Welding \& Fabrication, Vol.66, No 6, 12-14.

2. Sundarapandiyan C., Balamurugan A. and Mohan M., 2017. A Review on Under Water Welding Process. International Journal of Innovations in Engineering and Technology, Vol.8, No 1, 260-265.

3. Maksimov S., 2017. E.O.Paton Electric Welding Institute activity in the field of underwater welding and cutting.Vol.06, 37-45.

4. Blackman S.A. and Woodward N.J., 2003. Hyperbaric repair and hot-tapping of deepwater pipelines and risers. International Conference of Recent Developments and Future Trends in Welding Technology (2nd), Cranfield University, 4-5 Sept. 2003.

5. Patel H., Patel V. and Bareth R., 2016. An Assessment over Underwater Welding Technique. International Journal of Research, Vol.3, No 1, 493-499.

6. Labanowski J., Fydrych D. and Rogalski G., 2008. Development in underwater welding. 
7. Liu S, Rowe M., 2002. Progress in underwater wet welding: The Quintessential SMA Consumables. ASM Proceedings of the International Conference: Trends in Welding Research, Callaway Gardens Resort, Phoenix, Arizona, 15-19 April, 2002, 536-541.

8. Niu H., Tang D. and Lu T., 2012. Experimental Study on Structure and Property of Joints Welded with Underwater Hyperbaric Dry GMAW. Petroleum Engineering Construction, Vol.4.

9. Li K., Gao H. and Li H. 2014. Arc Behavior of Dry Hyperbaric Gas Metal Arc Welding. Advanced Materials Research, Vol.988, 245-248.

10.Baune E., Bonnet C. and Liu S., 2001. Assessing metal transfer stability and spatter severity in flux cored arc welding. Science and Technology of Welding and Joining, Vol.6, No 3, 139-148.

11.Lucas B., 1997. The flux - cored arc process for wet welding and cutting - an assessment. TWI document, Vol.3.

12.Haferkamp H, Bach F.W. and Hamkens J.H., 1990. Underwater wet welding of structural steels for the off-shore sector using "self-shielded" flux-cored electrodes. Welding and Cutting, Vol.5, 71-77.

13.Guo N., Wang M., Guo W. and Feng J., 2014. Flux-cored wire for underwater wet welding. Transactions of the China Welding Institution, Vol.35, No 5, 13-16.

\section{Контроль геометрических параметров сварного шва при мокрой подводной сварке}

\section{Хан Яанфей, Гуо Нинг, Фенг Чісай}

Аннотация. Водная среда оказывает значительное влияние на эффективность тепловложения в основной металл, значительно снижая коэффициент полезного действия дуги. В результате, при подводной мокрой сварке проплавление основного металла уменьшается по сравнению со сваркой на воздухе при одинаковых параметрах режима. Целью проведенных исследований было определить эффективность влияния параметров процесса подводной мокрой сварки порошковой проволокой рутилового типа на геометрические параметры металла шва - его ширину и глубину проплавления основного металла. При этом определяли коэффициент формы шва - отношение ширины к глубине проплавления (W/P). Установлено, что скорость сварки, скорость подачи проволоки и амплитуда колебаний сварочной горелки оказывают существенное влияние на отношение ширины к глубине проплавления сварных швов. Отношение W/P сварных швов значительно уменьшается с увеличением скорости сварки без колебаний сварочной горелки. Так, при сварке с поперечными колебаниями сварочной горелки с увеличением скорости подачи проволоки оно уменьшилось с 7,14 до 3,85 . И оно линейно возрастало с увеличением амплитуды колебаний горелки. Установлено, что скорость колебаний, удлинение вылета порошковой проволоки и напряжение дуги оказывают несущественное влияние на отношение W/P.

Ключевые слова: порошковая проволока, подводная мокрая сварка, отношение ширины к глубине проплавленияения. 